\title{
Modelling Tritium and Carbon 14 in the environment: A biomass-oriented approach
}

\author{
C. Tamponnet \\ Institute of Radioprotection and Nuclear Safety, DEI/SECRE, CADARACHE, BP. 1 , \\ 13108 Saint-Paul-lez-Durance Cedex, France, e-mail: christian.tamponnet@irsn.fr
}

\begin{abstract}
There are many existing models describing the behaviour of carbon 14 and tritium in the environment. There are all quite difficult to handle and data consuming because they are based on the precise description of the different and complex mechanisms of the carbon and hydrogen cycles.

A simplified model of transfer in the environment of tritium and carbon 14 is presented. It is based on the following assumptions: (a) the modelled radionuclides have an homogeneous repartition inside the biological compartments considered; (b) transfer flows of such radionuclides are proportional to the biomass changes in all the biological compartments; (c) time evolution of radionuclides isotopic equilibrium is discrete.

Such a dynamic approach is based on the use of growth models of biological systems (plants, animals, etc..). From the proposed conceptual model, 2 mathematical models are proposed: a one-pool model (organic carbon for carbon 14) and a two-pool model (organic tritium and tritiated water for tritium).
\end{abstract}

\section{INTRODUCTION}

Modelling the behaviour of radionuclides in the environment is one of the most important challenges in radioecology. Indeed, such models allow predictive time evolution of accidental contamination of the environment and of appropriate counter-measures.

Environment can be divided into different types of ecosystems. Each ecosystem is composed of a biotope and its associated biota. Time evolution of radionuclide contamination in the different parts of the biotope (soil, air and water) can be understood easily whatever the forms of the contaminant (aerosols, gaseous, attached to particles). But concerning the radionuclide contamination of the biota, one have to distinguish between radioactive isotopes of chemical elements which are part of the organic matter (C, H, O, N, S, P, etc...) and those which are not (K, Ca, Cs, Sr, Co, U, Pu, Am, etc..) being either minerals necessary to biological functioning or analogues or toxics.

For the latter, transfer of radionuclides to biota can be easily defined by aggregated parameters such as concentration factors (CFs) and transfer factors (TFs). For the former, such parameters cannot be used. In that case, transfer of such radionuclides is directly linked with physiological evolution of the growth of the considered biota.

\section{CONCEPTUAL MODEL}

This directly applies to the two main radionuclides of this group, which are the focuses of this paper: tritium and carbon 14. Both of them have natural and anthropic origins. 


\subsection{Chemical forms of carbon 14 and tritium in the environment}

Carbon 14 is released mainly as small organic molecules such as methane $\left({ }^{14} \mathrm{CH}_{4}\right)$, carbon dioxide $\left({ }^{14} \mathrm{CO}_{2}\right)$, and carbon monoxide $\left({ }^{14} \mathrm{CO}\right)$. Carbon monoxide and methane are oxidised either chemically or biologically into carbon dioxide. Therefore, the main chemical form in the biotope is carbon dioxide that can be found as it is in the atmosphere or as carbonates $\left(\mathrm{CO}_{3}{ }^{2-}\right)$ and bicarbonates $\left(\mathrm{HCO}_{3}{ }^{-}\right)$ in the hydrosphere.

Tritium is released mainly as small organic molecules such as methane $\left(\mathrm{CTH}_{3}\right)$, dihydrogen $(\mathrm{HT})$ and water (HTO). Dihydrogen and methane are oxidised either chemically or biologically into water. Therefore, the main chemical form in the biotope is tritiated water.

\subsection{Pools of carbon 14 and tritium in biota}

Both carbon 14 and tritium have concentrations in biota directly linked with the biomass production. Indeed, for each living being, one can define one chemical composition characterised by the following formula:

\section{$\mathrm{CH} \alpha \mathrm{O} \beta \mathrm{N} \gamma \mathrm{S} \delta \mathrm{P} \varepsilon$}

where $\alpha, \beta, \gamma, \delta$ and $\varepsilon$ indicate the occurrence of each of the chemical element compared to the one of carbon having an occurrence of 1 , in the dry biomass of the considered living element (either organism, organ or tissue).

Considering that at least $96-98 \%$ of the biomass is represented by these 6 chemical elements, one can extract for a given organism, organ or tissue its carbon and hydrogen concentrations as kg of $\mathrm{C}$ or $\mathrm{H}$ per kg of dry biomass.

But one can find 2 main differences. First, one can distinguish one pool of carbon 14 in organic matter: organic carbon, but one can distinguish two pools of tritium in organic matter: organic tritium and tritiated water. Second, both radionuclides are not seen exactly as their non-radioactive isotopes in biochemical reactions. Therefore, there is an isotopic discrimination that can be considered as negligible for carbon 14 but that has to be taken into account for tritium. Indeed, such a discrimination is mainly based on the relative mass of each isotope: the ratio ${ }^{14} \mathrm{C} /{ }^{12} \mathrm{C}$ is about 1.167 although the ratio $\mathrm{T} / \mathrm{H}$ is 3 .

\subsection{Chronic and Accidental releases of carbon 14 and tritium in biota}

Anthropic release of carbon 14 and/or tritium in the environment can either be chronic (continuous, controlled and small) or accidental (sudden, uncontrolled and large). In the first case, one can assume that a stable isotopic ratio is obtained in every compartment of the food chains. In the second case, such equilibrium is not obtained. Therefore, the kinetic aspects of biomass transfer in the food chains should be taken into account for the calculation of the time evolution of the carbon 14 [1] and tritium [2] pools in biota.

\section{MATHEMATICAL ONE POOL-MODEL}

Such model is used for carbon 14 in terrestrial ecosystems. We consider only one pool of carbon 14 in biota: the organic carbon 14 . 


\subsection{Chronic release of carbon 14 in biota}

\subsubsection{Contamination of autotrophs}

Plants are contaminated from carbon 14 released in the atmosphere [3] according to the following equation:

$$
[C 14]_{\text {veg }}=\frac{f_{\text {veg }}^{c}}{f_{\text {air }}^{c}} \cdot[C 14]_{\text {air }}
$$

with [C14 $]_{\text {veg }}$ activity of carbon 14 in fresh plants $\left(\mathrm{Bq} \cdot \mathrm{kg}^{-1}\right),[C 14]_{\text {air }}$ activity of carbon 14 in air (Bq. ${ }^{-3)}, f_{\text {air }}^{c}$ mass of carbon as $\mathrm{CO}_{2}$ in air $\left(\mathrm{kgC} . \mathrm{m}^{-3)}\right.$ and $f_{\text {veg }}^{c}$ carbon concentration in fresh plants $\left(\mathrm{kgC} . \mathrm{kg}^{-1}\right)$.

\subsubsection{Contamination of heterotrophs}

In the food chain, animals are contaminated by foodstuffs according to the following equation:

$$
[C 14]_{a n i}=\frac{\sum_{i=1}^{N}[C 14]_{i} \cdot R_{i, a}}{\sum_{i=1}^{N} f_{c, i} \cdot R_{i, a}} \cdot f_{a n i}^{c}
$$

with $[C 14]_{a n i}$ activity of carbon 14 in animal $\left(\mathrm{Bq} \cdot \mathrm{kg}^{-1}\right), f_{\text {ani }}^{c}$ carbon concentration in animal $\left(\mathrm{kgC} . \mathrm{kg}^{-1}\right), f_{c, i}$ carbon concentration in the $\mathrm{i}^{\text {th }}$ foodstuff $\left(\mathrm{kgC} . \mathrm{kg}^{-1}\right), R_{i, a}$ daily consumption of the $\mathrm{i}^{\text {th }}$ foodstuff by the animal (kg.d ${ }^{-1}$ ) and $[C 14]_{i}$ activity of carbon 14 in the $\mathrm{i}^{\text {th }}$ foodstuff (Bq.kg ${ }^{-1}$ )

\subsection{Accidental release of carbon 14 in biota}

\subsubsection{Contamination of autotrophs}

Plants are contaminated from carbon 14 released in the atmosphere according to the following equation:

$$
\left[C_{14}\right]_{\text {veg }}=\frac{f_{\text {veg }}^{c} \cdot F_{m}^{c}}{f_{\text {air }}^{c}} \cdot \frac{\sum_{i=1}^{N}\left[C_{14}\right]_{\text {air }}^{i} . \Delta M_{i}}{\sum_{i=1}^{N} \Delta M_{i}}
$$

with [C14] $]_{\text {veg }}$ activity of carbon 14 in fresh plants (Bq. $\left.\mathrm{kg}^{-1}\right),[C 14]_{\text {air }}^{i}$ activity of carbon 14 in air (Bq. $\mathrm{m}^{-3)}$ during period $\mathrm{T}_{\mathrm{i}}=\mathrm{t}_{\mathrm{i}}-\mathrm{t}_{\mathrm{i}-1} F_{m}$ proportion of carbon14 released in air as carbon dioxide, $\mathrm{f}_{\mathrm{c} \text {,air }}$ mass of carbon as $\mathrm{CO}_{2}$ in air $\left(\mathrm{kgC} . \mathrm{m}^{-3)}, \mathrm{f}_{\mathrm{c}, \text { veg }}\right.$ carbon concentration in fresh plants $\left(\mathrm{kgC} . \mathrm{kg}^{-1}\right)$ and $\Delta \mathrm{M}_{\mathrm{i}}$ increase of plant biomass $\left(\mathrm{kg}\right.$.time $\left.\mathrm{e}^{-1}\right)$ during period $\mathrm{T}_{\mathrm{i}}=\mathrm{t}_{\mathrm{i}}-\mathrm{t}_{\mathrm{i}-1}$. and considering that $\mathrm{t}_{\mathrm{N}}$ corresponds to the harvesting of the plant for future use as foodstuff. Moreover, parameter [C14 $]_{\text {air }}^{i}$ comes either from database or from diffusion model of carbon 14 and parameter $\Delta M_{i}$ comes either from database or from an existing plant growth model. 


\subsubsection{Contamination of heterotrophs}

When dealing with animals without any real growth of biomass, contamination by foodstuffs occurs according to the following equation:

$$
[C 14]_{a}^{t n}=[C 14]_{a}^{t(n-1)} \cdot\left(1-\frac{\Delta M_{a}^{t n}}{M_{a}}\right)+\frac{\Delta M_{a}^{t t} \overline{\left[C_{14}\right]_{a l i}^{t(n-1)}} \cdot f_{a}^{c}}{M_{a} \cdot f_{a l i, t(n-1)}^{c}}
$$

with [C14 $]_{a}^{t n}$ activity of carbon 14 in animal $\left(B q \cdot \mathrm{kg}^{-1}\right)$ at time $\mathrm{t}_{\mathrm{n}},[C 14]_{a}^{t(n-1)}$ activity of carbon 14 in animal (Bq.kg-1) at time $\mathrm{t}_{\mathrm{n}-1}, f_{a}^{c}$ carbon concentration in animal $\left(\mathrm{kgC}^{-1} \mathrm{~kg}^{-1}\right)$ and Ma animal biomass (kg). The following parameters: $\overline{\left[\mathrm{C}_{14}\right]_{a l i}^{t(n-1)}}$ Mean activity of carbon 14 in foodstuffs $\left(\mathrm{Bq} \cdot \mathrm{kg}^{-1}\right)$ at time $\mathrm{t}_{\mathrm{n}-1,}, \overline{f_{a l i, t(n-1)}^{C}}$ Mean carbon concentration in foodstuffs $\left(\mathrm{kgC}^{\mathrm{kg}} \mathrm{kg}^{-1}\right)$ during period $\mathrm{T}_{\mathrm{n}}=\mathrm{t}_{\mathrm{n}}-\mathrm{t}_{\mathrm{n}-1, \Delta M_{a}^{t n}}$ Renewed animal biomass during period $T_{n}=t_{n}-t_{n-1}$, are calculated according to the following equations:

$$
\overline{\left[C_{14}\right]_{a l i}^{(n-1)}}=\frac{\sum_{i=1}^{N 2}[C 14]_{i}^{t(n-1)} \cdot R, a}{\sum_{i=1}^{N 2} R_{i, a}}
$$

with: $\mathrm{R}_{\mathrm{i}, \mathrm{a}}$ Daily intake of the $\mathrm{i}^{\text {th }}$ foodstuff and $[C 14]_{i}^{t(n-1)}$ Activity of carbon 14 in the $\mathrm{i}^{\text {th }}$ foodstuff $\left(B q . \mathrm{kg}^{-1}\right)$ at time $\mathrm{t}_{\mathrm{n}-1}$.

$$
\overline{f_{a l i, t(n-1)}^{C}}=\frac{\sum_{i=1}^{N 2} f_{i, t(n-1)}^{c} \cdot R_{i, a}}{\sum_{i=1}^{N 2} R_{i, a}}
$$

with $R_{i, a}$ Daily consumption of the $\mathrm{i}^{\text {th }}$ foodstuff by animal $\left(\mathrm{kg} \cdot \mathrm{d}^{-1}\right)$ and $f_{i, t(n-1)}^{c}$ Carbon concentration in the $\mathrm{i}^{\text {th }}$ foodstuff $\left(\mathrm{kgC} . \mathrm{kg}^{-1}\right)$ during period $\mathrm{T}_{\mathrm{n}}=\mathrm{t}_{\mathrm{n}}-\mathrm{t}_{\mathrm{n}-1}$.

$$
\Delta M_{a}^{t n}=\frac{\sum_{i=1}^{N 2} R_{i, a} \cdot\left(1-f_{i}^{s}\right)+f_{\text {métab }} \cdot \sum_{i=1}^{N 2} R_{i, a} \cdot f_{i}^{s}+\left(M_{a} \cdot\left(1-f_{a}^{s}\right) \cdot \%_{I A C}^{E}+R_{b / a}\right)}{1-f_{a}^{s}}
$$

with Ma animal biomass $(\mathrm{kg}), \mathrm{f}_{\mathrm{s}, \mathrm{a}}$ part of dry matter in animal biomass, $\mathrm{f}_{\text {metab }}$ part of metabolised water in animal water, $\mathrm{f}_{\mathrm{s}, \mathrm{i}}$ part of dry matter in $\mathrm{i}^{\text {th }}$ foodstuff, $R_{i, a}$ daily consumption of the $\mathrm{i}^{\text {th }}$ foodstuff by the animal $\left(\mathrm{kg} . \mathrm{d}^{-1}\right), R_{i, b}$ daily consumption of water drink by animal $\left(\mathrm{kg} \cdot \mathrm{d}^{-1}\right)$ and $\%_{\mathrm{E}, \mathrm{IAC}}$ part of animal water coming from inhalation and cutaneous absorption.

Concerning animals with real growth of biomass, contamination by foodstuffs occurs according to the following equation:

$$
[C 14]_{a}^{t n}=[C 14]_{a}^{t(n-1)} \cdot\left(1-\frac{\Delta M_{a, s}^{t n}}{M_{a}^{t n}}\right)+\frac{\Delta M_{a}^{t n} \cdot \overline{\left[C_{14}\right]_{a l i}^{t(n-1)}} \cdot f_{a}^{c}}{M_{a}^{t n} \cdot f_{a l i, t(n-1)}^{c}}
$$

with Ma,tn animal biomass at time tn; $\Delta M_{a, s}^{t n}$ metabolic loss of biomass during period $T_{n}=t_{n}-t_{n-1}$, with $\Delta M_{a, s}^{t n}=\Delta M_{a}^{t n}$ - real growth of animal biomass during period $\mathrm{T}_{\mathrm{n}}=\mathrm{t}_{\mathrm{n}}-\mathrm{t}_{\mathrm{n}-1}$, the latter one being given either by a database or an animal growth model. 


\section{MATHEMATICAL TWO POOL-MODEL}

Such model is used for tritium in terrestrial ecosystems. We consider only two pools of tritium in biota: the organic tritium and tritiated water.

\subsection{Chronic release of tritium in biota}

\subsubsection{Contamination of autotrophs}

Plants are contaminated from tritium released in the atmosphere according to the following equation:

$$
[T]_{p v}=[T]_{a i r}^{H T O} \cdot\left[\left(1-0,7 \cdot f_{p v}^{s}\right) \cdot F D_{p v}+0,7 \cdot f_{p v}^{s} \cdot D I_{p v} \cdot \frac{f_{p v}^{H}}{f_{a i r}^{H}} \cdot F D_{f}\right]
$$

with $[\mathrm{T}]_{\mathrm{pv}}$ activity of tritium in plants (Bq.kg $\left.{ }^{-1}\right),[\mathrm{T}]_{\mathrm{HTO}, \text { air }}$ activity of tritium in air (Bq.kg-1), $\mathrm{f}_{\mathrm{s}, \mathrm{pv}}$ part of dry matter in plant biomass, $\mathrm{FD}_{\mathrm{pv}}$ dilution factor of $\mathrm{HTO}$ by soil water in plant, $\mathrm{DI}_{\mathrm{pv}}$ isotopic discrimination of tritium in plant, $\mathrm{f}_{\mathrm{H}, \mathrm{pv}}$ hydrogen concentration in dry plant biomass $\left(\mathrm{kgH}^{\mathrm{kg}} \mathrm{kg}^{-1}\right), \mathrm{f}_{\mathrm{H} \text {,air }}$ mass of hydrogen in air and $\mathrm{FD}_{\mathrm{f}}$ dilution factor of $\mathrm{HTO}$ by soil water in leaves.

\subsubsection{Contamination of heterotrophs}

In the food chain, animals are contaminated by foodstuffs according to the following equation:

$$
[T]_{p a}=\left(1-0,7 \cdot f_{p a}^{s}\right) \cdot[T]_{p a}^{H T O}+0,7 \cdot f_{p a}^{s} \cdot[T]_{p a}^{\text {org }}
$$

with $\mathrm{f}_{\mathrm{s}, \mathrm{pa}}$ part of dry matter in animal biomass and:

$$
[T]_{p a}^{H T O}=[T]_{a i r}^{H T O} \cdot\left[F D_{p v \cdot \%} \%_{E A}^{E}+F D_{f} \cdot \%_{A S}^{E}+R_{b / a i r}^{H T O} \%_{B}^{E}+\%_{I A C}^{E}\right]
$$

with $[\mathrm{T}]_{\mathrm{HTO}, \mathrm{pa}}$ activity of tritium in animal as tritiated water (Bq.kg-1), \% ${ }_{\mathrm{E}, \mathrm{EA}}$ part of animal water fromm water in foodstuffs, $\%_{\mathrm{E}, \mathrm{As}}$ part of animal water from dry matter of foodstuffs, $\%_{\mathrm{E}, \mathrm{B}}$ part of animal water from water drink and $\%_{\mathrm{E}, \mathrm{IAC}}$ part of animal water coming from inhalation and cutaneous absorption; and:

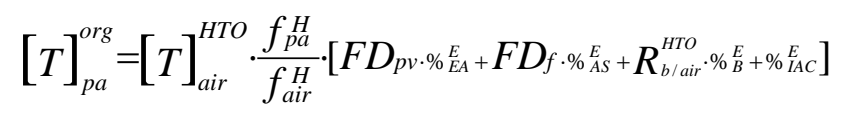

with $[T]_{\text {org,pa }}$ activity of tritium in animal as organic tritium (Bq.kg-1), $\mathrm{f}_{\mathrm{H}, \mathrm{pa}}$ hydrogen concentration in dry animal biomass $\left(\mathrm{kgH} \mathrm{kg}^{-1}\right), \mathrm{f}_{\mathrm{H} \text {,air }}$ mass of hydrogen in air, and

$$
R_{b / a i r}^{H T O}=\frac{[T]_{\text {boisson }}^{\text {HTO }}}{[T]_{\text {air }}^{\text {HTO }}}
$$

\subsection{Accidental release of tritium in biota}

\subsubsection{Contamination of autotrophs}

Plants are contaminated from tritium released in the atmosphere according to the following equations:

$$
[T]_{p v}=\left(1-0,7 \cdot f_{p v}^{s}\right) \cdot[T]_{p v}^{H T O}+0,7 \cdot f_{p v}^{s v}[T]_{p v}^{o r g}
$$




$$
\begin{gathered}
{[T]_{p v}^{H T O}=F D_{p v} \cdot F_{m} \cdot[T]_{N}^{a i r}} \\
{[T]_{p v}^{o r g}=f_{p v}^{H} \cdot D I_{p v} \cdot F D_{f} \cdot F_{m} \cdot \frac{\sum_{i=1}^{N} \frac{[T]_{i}^{a i r}}{f_{a i r, i}^{H}} \cdot \Delta M_{i}}{\sum_{i=1}^{N} \Delta M_{i}}}
\end{gathered}
$$

with [T] $]_{\text {air }}^{i}$ activity of tritium in air (Bq. $\mathrm{m}^{-3)}$ during period $\mathrm{T}_{\mathrm{i}}=\mathrm{t}_{\mathrm{i}}-\mathrm{t}_{\mathrm{i}-1}, F_{m}$ Proportion of tritium released in air as HTO, $\Delta \mathrm{M}_{i}$ increase of plant biomass $\left(\mathrm{kg}\right.$.time $\left.{ }^{-1}\right)$ during period $\mathrm{T}_{\mathrm{i}}=\mathrm{t}_{\mathrm{i}}-\mathrm{t}_{\mathrm{i}-1}$. and $\mathrm{f}_{\mathrm{H}, \text { arr, }}$ mass of hydrogen in air during period $\mathrm{T}_{\mathrm{i}}=\mathrm{t}_{\mathrm{i}}-\mathrm{t}_{\mathrm{i}-1}$.

\subsubsection{Contamination of heterotrophs}

When dealing with animals without any real growth of biomass, contamination by foodstuffs occurs according to equation 10 and the following equations:

$$
\begin{aligned}
& {[T]_{p a, t h}^{\text {HTO }}=[T]_{p a, t(n-1)}^{\text {HTO }} \cdot\left(1-\frac{\Delta M_{p a}^{t n}}{M_{p a}}\right)+A} \\
& A=\frac{\left[\sum_{i=1}^{N 2}[T]_{i, t n}^{H T O} \cdot R_{i, a} \cdot\left(1-f_{i}^{s}\right)+f_{\text {métab }} \cdot \sum_{i=1}^{N 2}[T]_{i, t h}^{o r g} \cdot R_{i, a} \cdot f_{i}^{s}+\left(M_{p a} \cdot\left(1-f_{p a}^{s}\right) \cdot \%_{I A C}^{E}+R_{b / a i r}^{H T O} \cdot R_{b / a}\right) \cdot[T]_{a i r, t n}^{H T O}\right]}{\left(1-f_{p a}^{s}\right) \cdot M_{p a}} \\
& \Delta M_{p a}^{t n}=\frac{\sum_{i=1}^{N 2} R_{i, a} \cdot\left(1-f_{i}^{s}\right)+f_{m e ́ t a b} \cdot \sum_{i=1}^{N 2} R_{i, a} \cdot f_{i}^{s}+\left(M_{p a} \cdot\left(1-f_{p a}^{s}\right) \cdot \%_{I A C}^{E}+R_{b / a}\right)}{1-f_{p a}^{s}}
\end{aligned}
$$

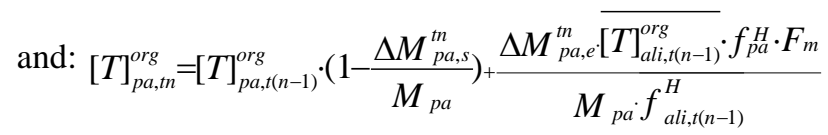

$$
\begin{aligned}
& \overline{[T]_{a l i,(n-1)}^{\text {org }}} \frac{\sum_{i=1}^{N 2}[T]_{i, t(n-1)}^{\text {org }} \cdot R_{i, a} \cdot f_{i}^{s}}{\sum_{i=1}^{N 2} R_{i, a} \cdot f_{i}^{s}} \\
& \overline{f_{a l i,(n-1)}^{H}} \frac{\sum_{i=1}^{N 2} f_{i, t(n-1)}^{H} \cdot R, a \cdot f_{i}^{s}}{\sum_{i=1}^{N 2} R_{i, a} \cdot f_{i}^{s}}
\end{aligned}
$$

Concerning animals with real growth of biomass, contamination by foodstuffs occurs according to the equations 10, 17 and 19 with the following changes:

$\Delta M_{p a}^{t n}$ (growing animal) $=\Delta M_{p a}^{t n}$ (from equation 18) - real growth of animal biomass during period $T_{n}=t_{n}-t_{n-1}$, the latter one being given either by a database or an animal growth model.

$\Delta M_{p a, s}^{t n}=\Delta M_{p a, e}^{t n}\left(\right.$ from equation 18) - real growth of animal biomass during period $\mathrm{T}_{\mathrm{n}}=\mathrm{t}_{\mathrm{n}}-\mathrm{t}_{\mathrm{n}-1}$, the latter one being given either by a database or an animal growth model. 


\section{Acknowledgments}

This research programme has been funded by IRSN and Electricité de France.

\section{References}

[1] Tamponnet C., Modélisation du transfert de carbone 14 dans l'environnement (IRSN DEI/SECRE Report 2004-019, Cadarache, 2004).

[2] Belot Y., Roy M. and Métivier H., Le tritium de l'environnement à l'homme (Collection IPSN, EDP Sciences, Les Ulis, 1996).

[3] NCRP, Screening models for release of radionuclides to atmosphere, surface water and ground (NCRP Report 123, 1996). 